\title{
Changing patterns of working time arrangements in registered collective agreements in New Zealand
}

\author{
Raymond Harbridge and Michael Dreaver*
}

Internal numerical flexibility (working hours, overtime and shift arrangements) is an important measure of the overall flexibility of the labour market. New Zealand's industrial legislation on working time arrangements is permissive and allows the parties to collective bargaining considerable freedom. However, awards and agreements have generally limited the 40 hour week to certain clock hours worked between Monday to Friday. Overtime and shift arrangements provide for work outside these clock hours. The research reported in this paper examines changes to working time arrangements in registered collective settlements in the $1987 / 88$ wage round. Over 30 percent of registered settlements contained a change to their working time arrangements with agreements being significantly more likely than awards to contain such a change. At least one more flexible working time arrangement was introduced in over 80 percent of those settlements.

\section{Introduction}

Labour market flexibility is often viewed in terms of wage flexibility, yet wage flexibility is just one of the components of flexibility identified and monitored by the OECD. The OECD has identified 5 components: external numerical flexibility, practises of "externalisation", internal numerical flexibility, functional flexibility and wage flexibility (OECD, 1986; Brünhes, 1988; Rojot, 1989). Work by the New Zealand Planning Council (1986) and more recently by Harbridge and McCaw (1989a) suggests that the New Zealand labour market contains a good degree of wage flexibility across industries, occupations and union categories. Little research has been undertaken on the other aspects of flexibility within New Zealand's labour relations system. This paper explores the extent of internal numerical flexibility, identifying changes to working time arrangements in registered settlements negotiated as part of the 1987/88 wage round.

The concept of internal numerical flexibility has various components. It can include employer requests for the calculation of time worked to be on an annual rather than a weekly basis, variation of working hours, an increase in the number and types of shifts

* Industrial Relations Centre, Victoria University of Wellington, P O Box 600, Wellington, New Zealand. This research was supported by a grant from the New Zealand Planning Council and grant 29/89 from the Internal Grants Committee, Victoria University of Wellington. The authors are grateful to Stuart McCaw for research assistance and to the journal's referees and the Editor for their constructive suggestions. 
worked, the provision of overlapping shifts, the provision of weekend shifts and various other methods of varying working hours over some specified period.

Employer requests for greater internal numerical flexibility come about for various reasons - both economic and social. The Labour Government's radical and controversia changes to the New Zealand economy (including the floating of the New Zealand dollar, the removal of sectoral subsidies and the elimination of many tariff and impor restrictions and the associated high interest rates along with what many perceive as an overvalued dollar) have led New Zealand into an economic recession. The recession and the more competitive product market experienced by employers has led them to seek greater use of workforce flexibility. In manufacturing enterprises, employers are seeking greater plant utilisation time and better use of their capital - in many cases seeking both increased productivity and reduced costs; in social and public service areas employers are seeking to reduce their overall wage costs to keep within Government imposed fiscal constraints. As a result, continuous shift work and night work are no longer confined to a few sectors. Further, working time arrangements are often no longer constrained as they were previously by fixed opening and closing times of businesses.

Workers may now be required to work during periods that have traditionally been devoted to the family and leisure activities. For example, changes to New Zealand's legislation in 1977 and 1980 to allow retail stores to trade as late as 9pm Monday to Friday, and freely on Saturdays, have led to retail employers seeking more flexible and less costly working time arrangements in the various awards and agreements covering retail staff. Workers required to work on a Saturday or in the evenings generally expect increased remuneration to compensate for loss of leisure or family opportunities. Employers eager to reduce wage costs will resist this. This conflict was highlighted recently by one union official who stated:

So far flexibility over hours of work has only involved income reductions for workers. Some employers are now seeking to remove penal rates and even overtime where over 8 hours are worked. Yet for many low paid workers, penal rates have not only compensated for working unsociable hours (e.g. late nights, Saturday) but are an integral part of the weekly wage (Conway, 1989).

In New Zealand, the legal provisions relating to the regular hours of work are contained in s 172 of the Labour Relations Act 1987. The Act prescribes that every award or agreement shall fix "at not more than 40" the maximum number of hour (exclusive of overtir De freater than 40 where either the parties to the document agree or where the Arbitration Commission in resolving a dispute determines that it would be impracticable to carry on efficiently any work to which the award or agreement relates if the working hours were limited to less than 40 . To date this provision appears little used. The Act also states that where the maximum number of hours per week is less than 40 , the parties or the Commission shall endeavour to fix the daily working hours so that no part of the working period falls on a Saturday or a Sunday. Thus the Act intends, but does not explicitly provide for the 40 hour week to be worked over 5 days excluding Saturday and Sunday. To that extent the Act can be seen as permissive of considerable variation in working time arrangements.

In reality most awards and agreements provide for 40 ordinary working hours to be worked between $8 \mathrm{am}$ to $6 \mathrm{pm}$ Monday to Friday, with provision for overtime payments to be made for work in excess of 40 hours and/or work outside these specified hours. In some industries and occupations, where the employer regularly requires work to be undertaken outside the clock hours or in addition to the ordinary hours of work, the provision of a shift clause allows the employment of workers without the payment of overtime rates of pay. These have been the traditional patterns of working time arrangements in New Zealand. However, those patterns are changing.
Following the passing of the Labour Relations Act 1987, employers associated with the New Zealand Business Roundtable stepped up their calls for a deregulated labour market and increased labour market flexibility (New Zealand Business Roundtable, 1988). Initially those calls focused largely on wage flexibility but more recently the focus has been on flexibility in hours of work as well. They were supported by the Governor of the Reserve Bank who claimed that more flexible hours were required in the best interests of New Zealand. The Governor recognised that employers might have to pay better rates to attract workers to work unattractive hours but argued that such better payments should be discretionary rather than mandatory as "to lock that into a sort of rigid award structure seems to be very regrettable" (Brash quoted in Pierce-Durance, 1988). Not all employers of course share the views of the Governor or the Business Roundtable. Morrison (1989) of course share the views of the Governor or the Business Roundtable. Morrison (1989)
implies that tensions between the Business Roundtable and the New Zealand Employers Federation reached new heights in 1989. Morrison argues that this tension was a contributing factor in the resignation of the Employer's Federation executive director, Dick Jessup. Jessup's interests, suggests Morrison, were with the everyday concerns of small and medium-size mainstream employers - employers who gave a "drubbing" to the Roundtable's deregulatory ideology, and who stated at a series of meetings throughout the country that the award system served them reasonably well.

Nothwithstanding this division in employer ranks about how far labour market deregulation should go, there has been growing employer demand for more flexible working time arrangements. This is evidenced by that fact that in the 1986/87 wage round, the last under the Industrial Relations Act 1973, just 8 percent of documents contained a change to one of the working time arrangement clauses. However, the next wage round, the first under the Labour Relations Act 1987, saw over 30 percent of settlements contain a change to one of the working time arrangements. The issue of working time arrangements has clearly become more important. This paper examines the $1987 / 88$ wage round, closely observing changes to working time arrangements, and attempts to classify those changes in the context of the flexibility argument.

\section{Methodology}

Using data that combines publicly available information: information about documents registered by the Arbitration Commission, information about union registration from the Registrar of Union's office, and information about industries and occupations in New Zealand available from the Department of Statistics, we have examined the 1987/88 wage round. The full methodology is set out in Harbridge (1988). Working time arrangements in each settlement are found in a number of clauses within the document. Each settlement was compared with its predecessor settlement in three respects - hours of work, shift and overtime clauses - to identify changed working time arrangements.

In classifying the changes reported we have grouped the data according to whether the observed change led to a more or less flexible working time arrangement. We have classified a change as more flexible if it either gives the employer greater control over working time arrangements and/or if the change reduces the employer's labour or other costs. Conversely, we have considered a change as less flexible if it either inhibits an employer's flexibility over working time arrangements and/or increases that employer's labour or other costs. For example, consider an award with clock hours of $8 \mathrm{am}$ to $6 \mathrm{pm}$. If these were extended so that they were now $7 \mathrm{am}$ to $7 \mathrm{pm}$ we would classify that as a more flexible arrangement - it allows.the employer to engage some or all workers at $7 \mathrm{am}$ without paying an overtime rate of pay for that hour worked between $7 \mathrm{am}$ and $8 \mathrm{am}$. Or consider an award containing a meal break of not less than 60 minutes. If that were reduced to not less than 30 minutes we would classify that as a more flexible arrangement as it enables the employer to compress the working day and thus save on workplace 
overheads - e.g. boiler costs, heating costs etc. An example of a less flexible arrangement would include the inclusion of clock hours in a document where none had previously been stated.

\section{The $1987 / 88$ wage round}

The first document relating to the $1987 / 88$ wage round was registered by the Arbitration Commission in September 1987 and the last in March 1989 - effectively this wage round, like earlier ones, lasted 18 months. In that period there were 684 documents Commission, having previously been state sector determinations issued under the provisions of the State Sector Conditions of Employment Act 1977. These state documents were simply transitional documents that codified the existing wages and conditions operating in a particular area of the state. For the purposes of the analysis in this paper, we have not included these state documents. For the purposes of this research then, we have examined the 588 private sector documents registered in the 1987/88 wage round. Of these 277 were agreements, 246 were awards, 29 w 36 were composite agreements.

We identified 191 (32.5 percent) private sector documents with changed working time arrangements. These settlements had changes to either or all of the hours of work, shift, or overtime clauses of the document. In 129 cases the settlement was directly comparable to a settlement in the 1986/87 wage round. In 36 cases the settlement was a new settlement registered for the first time and the settlement has been compared with the appropriate earlier document that had covered the workers. In 26 cases it had been one or more wage rounds since the settlement had been re-negotiated - we have classified such documents as "gap". Here we have been able to directly compare with the predecessor settlement - albeit a settlement negotiated 2 or 3 years earlier.

It was our observation that documents with changes to one aspect of working time arrangements - hours of work, overtime or shift - were likely to have changes to one or both of the other clauses. In fact, 39 documents had changes to all three working time arrangement clauses. There were 34 documents that changed both their hours of work and overtime clauses; 21 documents that changed both the overtime and shift clauses; and 11 documents that changed hours of work and shift provisions. The overall pattern of these changes was to introduce more flexibility in working time arrangements with over 80 percent of these documents containing at least one more flexible arrangement.

\section{Hours of work}

We have identified 115 different documents containing 176 changes to the hours of work clause - as we noted earlier, some documents contained more than a single change. Table 1 lists these 176 changes by document number according to whether the change led to more flexibility, an indeterminate change, or less flexibility. The appendix contains a list of the titles of each of the 191 documents cited in the tables. The document titles in the appendix are classified by industry. The data shows that more flexibility in hours of work clauses was achieved in 121 (69 percent) of the changes but that a more flexible work clauses was achieved in 121 (69 percent) of the changes but that a more flexible
hours of work arrangement was provided for in 97 ( 83 percent) of the changed documents.

More flexible hours of work provisions

Those changes which increased the flexibility of hours of work provisions fell into a number of categories. First, many settlements altered the "clock hours" - the span of hours within which the daily working hours could be worked. The most common form of clock hours is a provision allowing for work between 8am and 6pm daily, Monday to Friday - the ordinary hours of work. Work outside these hours would attract an overtime or penal payment. Some documents provided for additional hours or days of the week to be included in the ordinary hours provisions for some or all employees. Other documents extended the existing clock hour arrangements. Longer clock hours were recorded in 44 documents. There were 11 documents which extended both start and finishing times of documents. There were 11 documents which extended both start and finishing times of
the ordinary hours of work. In 17 documents the starting time was brought forward by 30 minutes and in 11 documents the finishing time was extended by 30 minutes. Extensions beyond 30 minutes at either or both ends of the day were rare with just 5 documents extending clock hours for 60 or more minutes. Changes to award provisions relating to the employment of workers in retail stores affected the hours of work provisions of 9 documents.

Second, changes achieving general increased flexibility in clock hours were made in 31 documents. These changes included a provision for clock hours to be varied by agreement with unions and individuals; the removal of a requirement that such agreements to vary must be in writing; an extension of the maximum time which could be worked before a meal break; and, in one case, the removal of the clock hours clause in toto

Third, two settlements increased the number of hours per week which some workers could be required to work - from 37 and a half to 40 hours.

Fourth, the taking of meal breaks within the ordinary clock hours was changed in 26 documents. In most of these documents the change reduced the mandatory meal break from 60 to either 45 or 30 minutes, or made the length of the meal break reducible on agreement. In a few documents, an express provision for work to continue through meal breaks was added.

Fifth, we have identified 18 documents containing other changes that we consider would increase the flexibility of hours of work provisions. These additional changes included an express expectation that childcare workers could not leave children in an early
childcare centre unattended while they took a meal or tea break, documents which made it easier to employ part time labour and one document which allowed for extra screenings in cinemas.

\section{Less flexible hours of work changes}

Less flexible arrangements were recorded in 36 documents. In 8 documents the number of hours to be worked per week was reduced and in 10 documents a reduction in the clock hours for some or all employees was introduced. In two documents, an express statement of clock hours was introduced where none had appeared before. Other restrictions we observed included reduction in scope for employing part time workers, the introduction of a provision requiring days off normally to be consecutive, and the addition of compulsory rest breaks.

\section{Indeterminate changes}

There were 19 documents where we were unable to determine whether the observed change was more or less flexible. The types of changes to hours of work clauses we identified but were unable to classify included the addition of shower and change time for sewer workers, the removal of a no-strike/no-go-slow guarantee by a union, and changes to various allowances associated with differing hours of work.

\section{Overtime}

Overtime occurs in two situations. First, where a worker works hours in excess of the ordinary hours of work, within the one week. Usually this will mean a worker will 
complete a 40 hour week before attracting overtime or penal payments. Second, overtime occurs where the worker works outside the clock hours contained in the document. Usually this will include work undertaken on a Saturday, Sunday or public holiday or (in the case of work undertaken between Monday and Friday) work commenced earlier than the starting time and/or concluded later than the finishing time in the document.

We have identified 84 documents containing a total of 104 changes to the overtime clause. Table 2 presents these 104 changes by document number and according to whether the change led to more or less flexibility, or was indeterminate. An increase in overtime flexibility was observed in 43 (51 percent) of the changed documents.

\section{More flexible overtime provisions}

More flexible overtime provisions were brought about by a number of different mechanisms. First, in 15 documents, standby or "on call" provisions were added or were
made more flexible. Second, in 6 documents a responsibility by the worker to work overtime was included in the overtime clause. Third, in 6 documents, provision was included for workers to be given time off in lieu of overtime payments. Finally, in 5 documents provisions restricting the working of overtime on the night of a union's regular meeting was removed. Apart from these changes, a general move towards flexibility was recorded in 31 documents. Changes here included a loosening in the requirement for notice of overtime to be given; an extension in the overtime which needed to be worked before a meal break had to be provided; a reduction in the minimum number of hours paid work which an employer had to provide an employee doing overtime; a removal of the requirement for a minimum break between periods of work; a reduction in the existing minimum break; and more provision for essential overtime.

\section{Less flexible overtime provisions}

We identified 28 changes which we classified as introducing less flexibility to overtime practices. These changes included the extension of the minimum break between periods of work, a change observed in 19 documents. This can restrict the length of overtime which can be worked if the employee is expected to start the next day at the normal clock-in time. Other less flexible practices included a stricter notification procedure before overtime could be requested by an employer and the removal of the call back provision.

\section{Other changes to overtime provisions}

We have identified a further 13 documents which contained a change to the overtime provision but where we were unable, without more detailed workplace based research, to classify that change as either a liberalisation or a restriction. One example of this was a document which allowed a company to refuse overtime to a worker who had not first completed 40 ordinary hours of work.

\section{Shifts}

In work situations where the employer regularly requires work to be undertaken outside the clock hours or in addition to the ordinary hours of work the provision of a shift clause allows the employment of workers without the payment of overtime rates of pay. Shift clauses typically define the hours of operation of the shifts and provide for additional allowances and benefits for workers engaged on such shifts. Table 3 lists these 148 changes by document number according to whether the change led to more flexibility, an indeterminate change (including the removal of or substantial changes to allowances), or less flexibility. The data shows that more flexibility in shifts clauses
was achieved in 72 (49 percent) of the changes. There were 35 changes ( 24 percent) where it is difficult to predict the flexibility effect without undertaking a workplace study to see how the changes have been implemented.

\section{More flexible shift arrangements}

Continuous 7-day shifts were introduced in 5 documents. Both twilight and rotating shifts were introduced in 2 documents. We have identified 37 documents which we have classified as encouraging shift flexibility by various mechanisms. These mechanisms included shift workers being made responsible to cover for absentees, shift clock hours being extended by providing for an earlier start than before, the deletion of a set shift roster and the addition of provision for a quick change shift.

\section{Less flexible shift arrangements}

Provisions which restricted shift flexibility were introduced into 41 documents. The types of restrictions introduced included a rider that shifts could only be worked in "unusual circumstances" rather than "as agreed"; a restriction on the days on which shifts could be worked; restrictions on the variations of shifts; the removal of the provision for broken shifts; and the removal of the whole shift clause.

\section{Discussion}

There are a number of features of our data that deserve further comment. First, changes to the working time arrangements in registered settlements have grown substantially from 8 percent of all documents in the 1986/87 wage round to over 32 percent in the $1987 / 88$ wage round. Two wage rounds are not sufficient to identify a trend, and data from a third wage round, the 1988/89 wage round, will not be available for some months. However, we believe on the basis of the growth of the changes identified, that working time arrangements will be a major focus of wage bargaining settlements over the next few wage rounds. Second, we observe that changes to one aspect of a document's working time arrangements have frequently been accompanied by changes to other working time provisions. This indicates that in some settlements, there has been some overall review of the working time arrangements and some co-ordination of the changes sought and agreed to. Third, our data shows that the overall pattern of the changes introduced is towards more rather than less flexible working time arrangements. Fourth, with one exception, we have been unable to discern any pattern between documents that have changed their working time arrangements. No particular industry, occupational group, or union appears to have been any more likely to produce a changed working time arrangement in their 1987/88 settlement than any other. The exception was that agreements, as a particular type of settlement, were statistically significantly more likely to have a changed working time arrangement than were other types of settlements. Agreements are generally single employer - single union settlements covering often just one workplace and to that extent they are often "enterprise" settlements. They almost invariably contain wage rates that are substantially better than those contained in the relevant award. We have already shown that over 80 percent of changed documents contained at least one more flexible working time arrangement and agreements are very much part of that pattern. As individual employers have grappled with the economic recession, it is hardly surprising that so many agreements contain changed working time arrangements generally designed to give the employer greater control over working time arrangements and in many cases reduce employer costs. 


\section{Conclusion}

Our findings based on our research of the 1987/88 wage round indicate that employers were able to introduce change to working time arrangements in many single union-single employer settlements. Our expectation is that, as the New Zealand economy goes further into recession, employers will be able to successfully wrest other concessions related to working time arrangements from unions. Further, it is our expectation that, having been successful in making working time arrangements more flexible in many agreements, employers will seek more flexible arrangements in the national awards. As yet it is far too early to attempt any detailed numerical analysis of the results of the 1988/89 wage round but the publicly reported positions of some parties lend credence to our view. At the commencement of the 1988/89 wage round, two "senior union negotiators" in Auckland, Electrical Workers union secretary, John Fisher, and Distribution Workers Federation advocate, Peter Conway, claimed that the employers had adopted a co-ordinated approach on flexible hours. Fisher claimed that this co-ordination was "killing the round and is a deliberate policy to do away with awards" (Fisher and Conway quoted in Barrett, 1988).

Twelve months later, employer pressure for flexibility in hours and working time arrangements has held up the settlement of three of the country's largest awards - the General Clerical Workers, the Licensed Hotels, and the Tearooms and Restaurants awards. The central issue in the Licensed Hotels negotiations was an employer claim for a 10 hour/4 day week without the payment of overtime. In the Tearooms and Restaurants document, the central issue was over an employer claim for the reduction of the 4 hour minimum daily payment to a 2 hour minimum. In the case of the Clerical document, the issue was an employer claim for the removal of the provisions of Clause 13 of the award which guarantees the weekly wage to all workers engaged for more than 30 hours per week. Unions have claimed that in all three awards the "real agenda" of the employers is the destruction of occupationally based awards such as these. Employers have dismissed conspiracy suggestions as nonsense (e.g. see Barrett 1989; Cullen, Slater and Clark quoted in Walsh 1989; and various commentators in Unity, 1989).

The issues raised in these disputes concern internal numerical flexibility (over hours, overtime and shifts, etc.) but also encompass the wider issue of external numerical flexibility - the casualisation of work and increased use of part-time rather than full-time workers. There can be no doubt that employers in these three sets of negotiations have identified their objectives and are using a tactical approach to achieve the flexibility they desire. One employer party to the Licensed Hotel award filed for a new separate award for its group of companies; many of the employers affected by the negotiations have passed a wage increase on to their workers as if the award had been settled. These strategies have severely weakened the union's ability to persuade their own members that the dispute is worth continuing. Employers seem to have realised the power of their position, the weakness of the unions amongst its own membership and as a result it would be no surprise to see the employers hold out for further concessions or refuse to settle these awards at all. The overall impact of these three disputes and the 1988/89 wage round altogether will not be seen for some time but certainly employers will have achieved some greater flexibility in working time arrangements. It is our intention to monitor and report on consequent wage rounds and the emergent changes to internal numerical flexibility in registered collective bargaining.

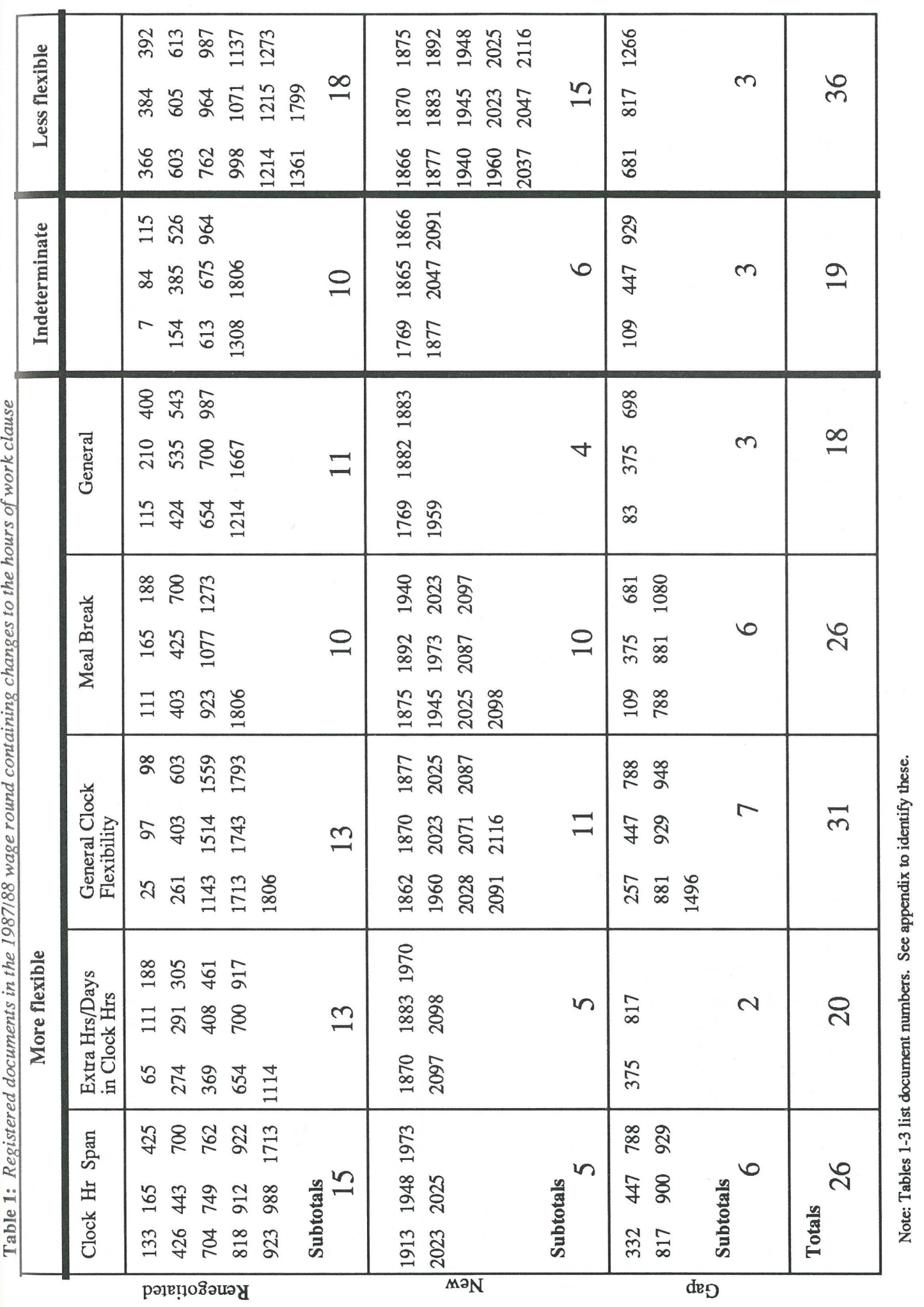




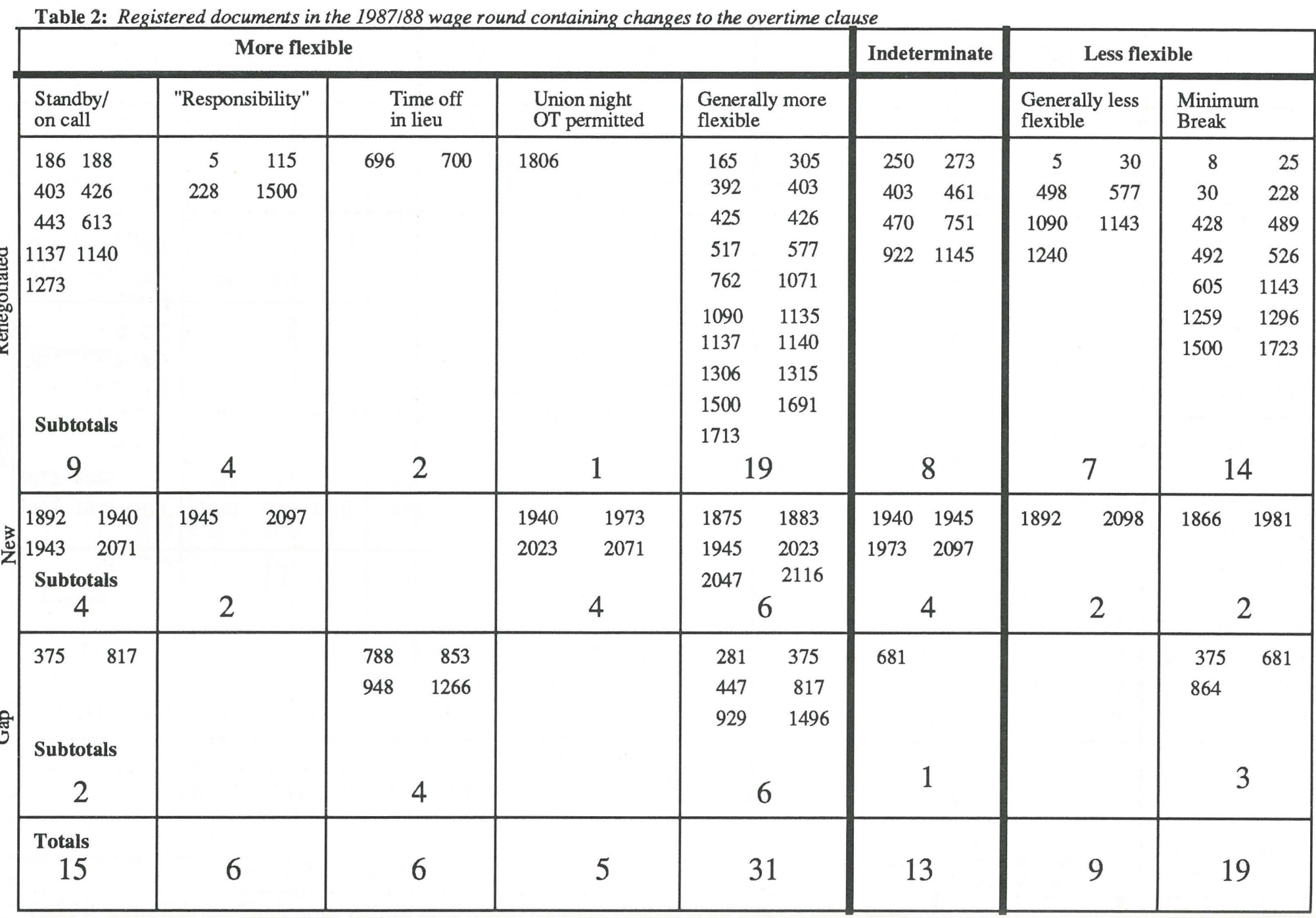

Table 3: Registered documents in the 1987/88 wage round containing changes to the shift clause

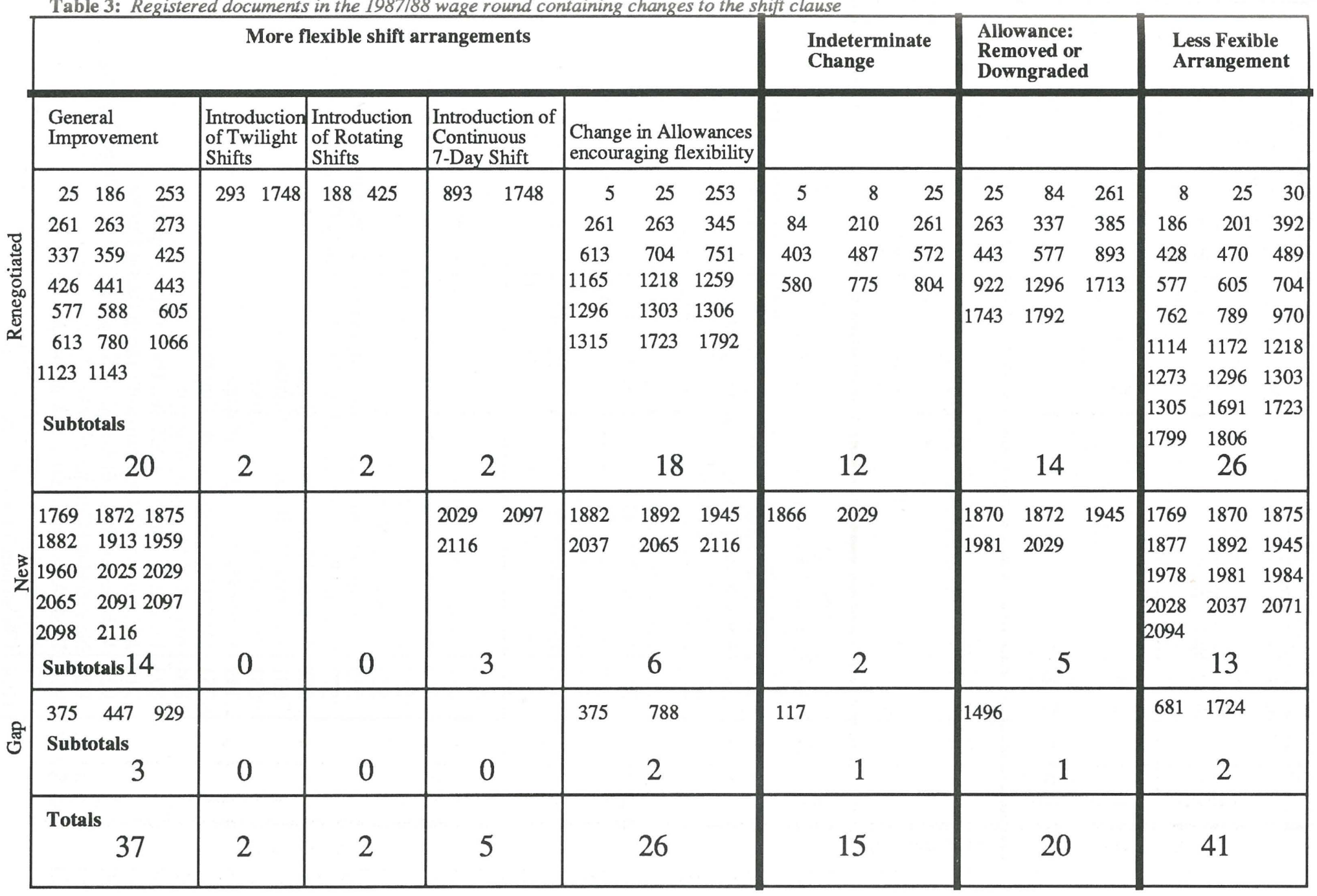


Appendix: Document numbers and titles classified by industry

Document Document Title

\begin{tabular}{l|l|l|l}
\hline Agriculture & 1214 & NZ Dairy Farm Workers \\
\hline
\end{tabular}

1215 NZ Arable and Meat (except Sheep Meat) Farm or Station Workers

1316 NZ Sheep Meat and Wool Farm or Station Workers

Mining

1080 Offshore New Zealand Drilling Rig R.O.V. Operators

1240 Shell B.P. and Todd Oil Services Limited Tradesmen \& Related

1960 RA Hanson Co, Gry River Gld Mng Ltd, Giant Resources NZ Ltd

2071 Palmerston North City Corporation Gasworkers and Gasfitters

Manufacturing

Ashley Meat Kaiapoi Plant (COT)

Waitaki Intl. Ltd Dunedin Plant Slaughter \& Abattoir Workers NZ Soft Drink and Cordial Workers

25 Coopers Animal Health NZ Ltd Employees

NZ (except Marlborough) Brewery and Bottling House Workers

Wanganui Abattoir Workers

98 Northern and Wellington Tobacco Workers

117 Caxton Paper Ltd Pulp \& Paper Workers COT

137 Nestle (NZ) Ltd, Papatoetoe Employees

154 NZ Synthetic Fuels Corp Ltd Maintenance Technicians \& Related

165 James Hardie \& Co. Pty Ltd, Fibre Cement Products Workers

210 NZ Wine \& Fruit Wine Industry Employees

228 Carter Oji Iokusaku Pan-Pacific Ltd Security Officers

253 Carter Oji Iokusaku Pan-Pacific Ltd Electricians

263 Carter Oji Iokusaku Pan-Pacific Ltd Factory Engineers

273 Milburn NZ Ltd Westport Establishment Employees (COT)

330 NZ Synthetic Fuels Corporation Ltd Process Technicians

345 Davis Gelatine NZ Ltd Factory Employees

403 Ready-Mix Concrete Drivers Employed in Cant. Labour District

425 Wilsons (NZ) Portland Cement Ltd Cement Works Employees

426 Golden Bay Cement Works Employees

443 NZ Brewing Industry Trades Engine Drivers \& Associated Worker

487 NZ (except Northern and Westland) Saddlers \& Canvas Workers

492 Northern, Taranaki, Wgtn. \& Canterbury Soap \& Candle Workers

Petralgas Chemicals NZ Ltd Shift Engineers

526 Taranaki \& Wellington Tanners

535 Milburn NZ Ltd, Cape Foulwind, Drivers \& Operators (COT)

577 Nissan Manufacturing Ltd Auckland Assembly Plant Engineering

588 Auckland Sugar Refinery (Sugar Workers)

601 Winstone Wallboard Employees

681 Waitaki Meats Ltd Employees

749 Victor Plasters Ltd Employees

751 McKechnie Group Works Employees

804 Abels Ltd Margarine Workers

893 Lactose Company of NZ Ltd, Hawera Employees

893 Lactose Con

912 J.C. Hutto NZ Lid Frankton Brawch B.

922 Vehicle Ass NZ Ltd Manukau \& Sylvia Park Ass Plnts Engnring

923 New Zealand Concrete Workers

998 Bluff Aluminium Smelter Operating

077 Malvern Abattoir Ltd Employees

1114 Christchurch Press Co Ltd, Drivers
Appendix (cont'd): Document numbers and titles classified by industry

Document

Document Title

\begin{tabular}{l} 
Number \\
\hline Manufacturing 1137 Wellington Ready-Mix Concrete Industry Workers
\end{tabular}

\begin{tabular}{l|l|l} 
(cont'd) & 1140 & Wilsons NZ Portland Cement Ltd NLD Drivers \& Storepersons
\end{tabular}

1143 Rothmans of Pall Mall (NZ) Ltd Napier Factory Engineers COT

1165 Abels Ltd Stationary Engine Drivers, Firemen, Greasers \& Asstnts

1273 NZ Industrial Gases Ltd, Drivers

1296 NZ Fabrics Ltd Mount Wellington Engine Drivers \& Assistants

1303 NZ Starch Products Ltd Stationary Engine Drivers

1305 Griffin \& Sons Lid Avondale Factory Stationary Engine Drivers

1306 Gynthetic Dys Lew

1306 Synthetic Dyeworks Stationary Engine Drive

1308 Nestle NZ Ltd Stationary Engine Drivers

1315 Bonds (NZ) Ltd, Otara, Auck. Engne Drvers, Firemn, Greasers, etc.

1496 Dominion Salt Ltd, Lake Grassmere, Vacuum Salt Refinery Plant

1500 Carter Oji Iokusaku Pan-Pacific Ltd Drivers Workers

1559 Northern Paint \& Varnish \& Printing Ink Workers

1713 Ford Motor Co NZ Lid Alloy Wheel Plant (engineers)

1723 Ford Moty Co NZ Lid Alloy Wheel Plant (enginers)

172 Station (NZ) Ltd

1726 Wattie Ind (Cons Div) Tip Top Ice-Cream Co Mt Wn Stat Drivers

1743 Assoc British Cables \& Austral Standard Cables Eng Maintenance

1748 Aspak Industries Ltd Margarine Workers

1792 James Hardie \& Co Pty Ltd Penrose Stationary Engine Drivers

1799 Austral Specialised Vehicles NZ Ltd Porirua

1806 NZ Refining Co Ltd Engineering Maintenance Workers

1862 NZ Ref ing Co Com Engin

1872 James Hardie Impey Ltd, Benhar Employees

1875 Waitaki International Ltd, Green Island Food Processing Workers

1882 Mainland Products Ltd

1892 General Motors NZ Ltd Coachworkers

1945 Nestle NZ Ltd Cambria Park

1978 NZ (with exceptions) Ready-Mix Concrete Drivers

1981 Cedenco Foods Ltd Engine Drivers

2023 Ford Motor Co NZ Ltd Parts \& Service Warehouse

2025 Ford Motor Co NZ Ltd Alloy Wheel Plant

2029 Dominion Oil Rfng Co Ltd Onehunga Stationary Engine Drivers

2037 NZ Breweries Ltd, Auckland Brewery Security Officers

2047 Waitotara Meat Co Ltd Employees

2094 Otago \& Southland Ready-Mix Concrete Drivers

Energy

\section{Dunedin City Council \& Gasworks Employees}

375 Auckland Electric Power Board Officers (COT)

470 Northern Labour District Electrical Supply Authorities Officers

489 NZ (except Cant \& Wstlnd) Electrical Wrkrs (Elec Spply Auth etc)

864 Wst Coast Electric Pwer Bd Electrical Workers Linemen \& Asstnts

1259 Hutt Valley Energy Board's Electrical Workers

1469 Wellington Gas Workers

1724 Hamilton City Council Gasfitters \& Gasworkers

1948 Otago Electrical Supply Authorities Officers

2071 Palmerston North City Corporation Gasworkers \& Gasfitters

2091 Taranaki, Wn, Marl., Nn \& Westld Electric Power Bds'Officers 
Appendix (cont'd): Document numbers and titles classified by industry

\begin{tabular}{|c|c|c|}
\hline \multicolumn{3}{|c|}{$\begin{array}{l}\text { Document } \\
\text { Number }\end{array}$} \\
\hline \multirow[t]{8}{*}{ Construction } & 186 & NZ Fire Sprinkler Installation Workers \\
\hline & 580 & Taranaki Cool Stores Service Engineers \\
\hline & 1066 & Clyde Dam Construction Employees \\
\hline & 1090 & NZ Synthetic Fuels Corpn Ltd Contractor Tradesmen \& Related \\
\hline & 1481 & Maui Offshore Diving Employees \\
\hline & 1913 & Downer \& Company Drivers \& Operators \\
\hline & 1940 & NZ Plumbers, Gasfitters \& Drainlayers Contractors \\
\hline & 2065 & Wilkins \& Davies Ltd Drivers \& Operators \\
\hline Wholesale/ & 65 & NZ Retail Pharmacists Assistants \\
\hline \multirow[t]{10}{*}{ Retail } & 274 & NZ Cake Shop Employees \\
\hline & 291 & NZ Fish Shop Employees \\
\hline & 305 & NZ Retail Grocery \& Supermarket Employees \\
\hline & 366 & NZ Tearooms \& Restaurant Employees \\
\hline & 369 & NZ Retail (non-food) Employees \\
\hline & 408 & NZ Fruit \& Vegetable Shop Employees \\
\hline & 654 & NZ Butchers \\
\hline & 1123 & Maui Offshore Catering Employees \\
\hline & 1970 & Nthn Labour District Retail Pharmacists Assistants \\
\hline & 2097 & NZ Offshore Oil Exploration Catering \& Domestic Workers \\
\hline \multirow[t]{13}{*}{ Transport } & 359 & NZ Harbour Boards' Employees \\
\hline & 572 & Nthn, Cant, Westld \& HB Bulk Freight Forwarders (Stores) \\
\hline & 603 & Auckland Harbour Board Electricians \\
\hline & 675 & North Shore Ferries \& Gulf Ferries Employees \\
\hline & 775 & NZ Ships' Watchmen, Ships' Headwatchmen \& Ships' Patrolmen \\
\hline & 1145 & Williams Rochester Ltd Jetty Operators \\
\hline & 1691 & Bilmans Mgmt Ltd (AnsttNZ \& Anstt Air Frght) Arcrft Eng Wrkrs \\
\hline & 1769 & Dunedin City Council Public Passenger Transport Workers \\
\hline & 1793 & Mount Cook Group Ltd Airline Traffic Officers \\
\hline & 1866 & Waimangu Thermal Valley Tours Engine Drivers \\
\hline & 1959 & Invercargill City Council Public Passenger Transport-Drivers \\
\hline & 2097 & NZ Offshore Oil Exploration Catering \& Domestic Workers \\
\hline & 2098 & New Plymouth City Council Public Passenger Transport \\
\hline \multirow[t]{5}{*}{ Finance } & 83 & Wellington Chartered Accountants Employees \\
\hline & 133 & Nelson Public Accountants Employees \\
\hline & 704 & New Zealand Insurance Workers \\
\hline & 905 & NZ (except Marl) Actors \& Related Performers etc. \\
\hline & 1865 & Crown Watching \& Comm Security Services NZ Sec Officers \\
\hline \multirow[t]{9}{*}{ Public Service } & 30 & NZ (except Cant \& Westld) Hospital \& AHB Drivers \\
\hline & 109 & Cant, South Cant \& Ashburton Hosp Bds Clerical \\
\hline & 188 & Auckland St John Ambulance Officers \\
\hline & 332 & Hutt Valley Drainage Bd Technical Professional, Clerical etc. \\
\hline & 384 & NZ (except Westland) Private Hospital Nurses \\
\hline & 400 & Wellington Free Ambulance Service Inc Drivers \\
\hline & 424 & NZ Commercial Live Performances \\
\hline & 428 & NZ AHB \& Hosp Bds Plumbers \& Gasfitters \\
\hline & 498 & NZ Photographic Processing \& Related Printing Employees \\
\hline
\end{tabular}

Appendix (cont'd): Document numbers and titles classified by industry

\begin{tabular}{l|l|l}
\hline \multicolumn{3}{c}{ Appendix (cont'd): } \\
\multicolumn{2}{c}{ Document } \\
Number \\
\hline Public Service & 543 & Nthn, Taranaki \& Wn Lbr Districts Motion Picture Projectionists \\
(cont'd) & 605 & Cant \& Westld Ambulance Driving Officers \\
613 & Automobile Assn (Central) Inc, Officers \\
789 & NZ (ex. HB, Wn, Wstld, Otgo, Sthld, LD) AHB Pntrs \& Decorators \\
853 & Northcote Borough Council Officers \\
917 & Cant \& Westld Laundry Workers, Dyers \& Dry Cleaners \\
964 & New Zealand University Technicians \\
970 & Dn Cty Cncl \& Dn Drainage \& Sewerage Bd Carpenters \& Related \\
987 & NZ (ex Taranaki, Wstld, Otgo \& Sthld) Erly Chldhood Workers etc \\
1071 & Nn Catchment Bd \& Rgnal Water Bd Technical, Prof, Admin, etc. \\
1514 & Sth Island Motion Picture Projectionists \\
1667 & New Zealand Practice Nurses \\
\hline 1877 & Pacific Tourways Ltd Christchurch Drivers \\
1883 & Northern Theatres \& Places of Amusement Employees \\
1973 & New Plym CC, Wanganui CC, Levin BC, Gasftters \& Gasworkers \\
& 2087 & Otago \& Sthld Laundry, Drycleaning \& Dyeing Workers \\
2116 & Nelson AHBs Clerical \& Other Officers
\end{tabular}

\section{References}

Barrett, Ross (1988) Union negotiators accuse employers of award hypocrisy National Business Review 21 November:5.

Barrett, Ross (1989) Occupational giant heading for a fall National Business Review 9 June:9.

Brünhes, B (1988) Labour flexibility in Europe: a comparative analysis of 4 countries Paris, OECD.

Conway, Peter (1989) Why do unions oppose labour market reform? New Zealand Tribune 3 April:9.

Harbridge, Raymond (1988) The way we were - a survey of the last wage round negotiated under the Industrial Relations Act 1973 New Zealand journal of business 10:48-65.

Harbridge, Raymond and McCaw, Stuart (1989a) Registered settlements and wage flexibility in the New Zealand private sector: 1984 - 1988 Wellington, Industrial Relations Centre Working Paper 2/89.

Harbridge, Raymond and McCaw, Stuart (1989b) The first wage round under the Labour Relations Act 1987: Changing relative power New Zealand journal of industrial relations 14(2):149 - 167.

Morrison, Alastair (1989) Nats trot out the gospel...according to Roundtable The Dominion 13 October:13.

New Zealand Business Roundtable (1988) Labour markets and employment: New Zealand Business Roundtable statements on labour relations Auckland, New Zealand Business Roundtable. 
New Zealand Planning Council (1986) Labour market flexibility: New Zealand Planning Council Monitoring Group Report Wellington, New Zealand Planning Council.

OECD (1986) Labour market flexibility Paris, OECD.

Pierce-Durance, Elizabeth (1988) Brash call for flexible hours National Business Review 22 November:5.

Rojot, Jacques (1989) Internal labour market flexibility Paris, OECD.

Unity (1989) Booze barons confronted and How far will they go? Unity 14 April:3.

Walsh, Lynne (1989) Employers out to bust national awards: unions Evening Post, 24 June:3. 